\title{
Model for sustainability implementation and measurement in construction sites
}

\author{
Ludimilla de Oliveira Zeule $^{1}$ | Sheyla Mara Baptista Serra ${ }^{1}$ \\ José Manuel Cardoso Teixeira²
}

${ }^{1}$ Civil Engineering Postgraduate Program, Civil Engineering Department, Federal University of São Carlos, São Carlos, São Paulo, Brazil

${ }^{2}$ School of Engineering, Civil Engineering Department, University of Minho, Guimarães, Portugal

\section{Correspondence}

Sheyla Mara Baptista Serra, Civil

Engineering Postgraduate Program, Civil Engineering Department, Federal University of São Carlos, São Carlos, São Paulo, Brazil. Email:sheylabs@ufscar.br

\begin{abstract}
Sustainable practices at construction sites should be considered from the start of the project, meaning during the design phase. A model for the implementation of sustainability at a site is an important management tool, and its adoption can indicate good practices and propose an assessment of local conditions. Thus, the main contribution of this article is to propose a practical model to evaluate the level of implementation of sustainable practices at construction sites. The model was based on sustainability certifications and validated at six construction sites in Brazil. The results indicate that construction companies that possess environmental certifications have better levels of implementation of good practices at their work sites. However, it was noted that it is not necessary for a company to obtain an environmental certification; rather, it is necessary for sustainability strategies to become corporate culture.
\end{abstract}

\section{KEYWORDS}

civil construction, construction site, environmental certification, sustainability

\section{1 | INTRODUCTION}

In recent years, sustainability has become one of the main focuses for the construction enterprises at all phases of their projects' life cycle: design, construction, and use (Zou \& Couani, 2012). The strengthening of sustainability is dependent on the rational use of systems and ecologically sound construction techniques, which must be combined appropriately to define the design parameters (Ahmad, Thaheem, \& Anwar, 2016). In fact, sustainable construction presents several benefits, not just environmental, but also economic and social. Construction projects that consider "green operations" benefit from decreased operational costs, improvements regarding the security and health of workers and occupants, and the rational use of natural resources, among other advantages (Halliday, 2008; Olanipekun, Chan, Xia, \& Ameyaw, 2017).

Interest in sustainability has extended to the construction process, creating growing interest by the construction industry in developing their activities in a sustainable fashion, (i.e., in producing sustainably) (Dong \& Ng, 2016; Thomas \& Costa, 2017; Zhang, Wang, Hu, \& Wang, 2017).

The active management of sustainable performance can provide significant improvements in the efficiency and profitability of a construction business (Construction Industry Research and Information Association, 2001; Marcelino-Sádaba, González-Jaen, \& PérezEzcurdia, 2015; Soto-Acosta, Cismaru, Vătămănescu, \& Ciochină, 2017). It is important to develop quantitative measures (indicators) with which companies can measure the sustainability of their businesses (strategic indicators) and activities (operational indicators). Shen, Li Hao, Tam, and Yao (2017) proposed a sustainable performance checklist to be used throughout the life cycle of construction projects. Based on a review of 47 academic publications in the area of building projects published between 2006 and 2015, Olanipekun et al. (2017) identified the need to create specific indicators for the owner's commitment about environmental concerns. The owners could thus know in advance the main sustainability guidelines that would promote the best performances of their businesses.

The improvement in sustainable performance starts with a commitment toward sustainability at a company's higher decision-making levels, which is accomplished through the adoption of sustainable practices throughout the entire production chain (Zou \& Couani, 2012), with benefits to project performance, and optimization of cost, time, and quality. The recognition of sustainable practices in construction is nowadays done through programs of environmental certification. In addition to showing the commitment of organizations to 
sustainability, the certification labels highlight good practices and work as quality parameters incorporated into the building. The best-known certification labels in Brazil are:

- Building Research Establishment Environmental Assessment Method (BREEAM) (Building Research Establishment, 2009),

- Leadership in Energy and Environmental Design (LEED) for New Construction \& Major Renovation (U.S. Green Building Council, 2009),

- AQUA-HQE process, based on the French label HQE (Haute Qualité Environnementale),

- Foundation Carlos Alberto Vanzolini (FCAV) (FCAV, 2013), and

- Blue House Seal from the Federal Savings Bank (Caixa Econômica Federal [CEF]) (CEF, 2010).

\section{The recognition of sustainable practices in construction is nowadays done through programs of environmental certification.}

According to the certifying agent, the Green Building Council (GBC), Brazil, is the country with the fourth highest number of sustainable buildings in the world, and it has the largest number of LEED-certified enterprises, behind only Canada, China, and India, in a list of 167 countries (GBC, 2018). In Brazil, there are 1,345 registered and 533 certified projects. According to the GBC, the green construction market in Brazil has strengthened over the last 10 years, with the engagement of the supply chain involving construction companies, architects, product suppliers, and services.

Research has also contributed to the understanding of the value of the certification process and to comparing certification labels' issues and metrics according to Grunberg, Medeiros, and Tavares (2014), Lee (2013), and Andrade and Bragança (2016). Generally speaking, environmental certifications present guidelines that need to be considered or followed in order for an enterprise to obtain a sustainability label. In spite of these guidelines and considering that the certification processes are currently well consolidated, it is still necessary to perform additional studies to delve further into the appropriate guidelines for the application of these processes to the implementation phase of construction work, which is a stage of significant impact on the environment and the construction site surroundings. In fact, the sustainability assessment methods in construction should consider a multidimensional approach (Ding, 2008), which should necessarily include the implementation phase of the work for the reasons above mentioned.

Thus, from a comparative study among the environmental certification labels focused on the implementation phase of the project, the objective of this study is to present a management methodology based on the proposition of an evaluation protocol and sustainability implementation on building construction sites. To accomplish this task, construction sites with LEED or AQUA-HQE environmental labels and social housing construction ventures (HIS) situated in diverse locations in Brazil (southeast and northeast) were visited to compare against and validate the proposed evaluation method. Finally, the results and limitations found in the application of the evaluation tool are discussed.

\section{2 | CONSTRUCTION SITE SUSTAINABILITY}

The construction stage of a building accounts for a significant portion of the negative impacts to the environment, mainly those related to the loss of materials and the generation of waste, and also in regard to interference in activities and conditions in the vicinity of the construction work (Zou \& Couani, 2012). Therefore, the construction phase must be considered to implement sustainable actions and minimize the impact of work on the environment.

The problems related to the construction phase are recurrent. According to Alarcón and Mardones (1998), the problems exist due to the lack of interaction between the design and construction phases. It has also been observed that although this problem has been argued and questioned for about 20 years, it persists. Choudhry, Gabriel, Khan, and Azhar (2017) warn that this lack of interaction still occurs, and that the most common changes are due to owners requesting design changes due to financial problems and lack of skilled labor in the construction market.

The environmental impact of construction is influenced by the entire production chain: extraction of raw materials, production and transportation of materials and components, design and projects, implementation (construction), use and maintenance practices, and at the end of its useful life, the demolition/disassembly, as well as the disposal of waste generated throughout the lifespan. Thus, the task of implementing sustainability practices should start even before the actual building project commences to set a management philosophy and to spread sustainability over the next steps in the process (Olanipekun et al., 2017). The design phase acquires great importance because it includes most of the decisions relevant to the sustainability of the building. Likewise, the design phase is very important for the sustainability of the construction phase. However, reality shows that the layout of construction sites is not always carried out to ensure that sustainability practices are implemented during the construction of the buildings.

Parallel to the adoption of sustainability practices on construction sites, various initiatives have been proposed in the literature for the management of sustainability during the execution of the project work:

- Chen, Li, and Wong (2002), in research developed in Hong Kong, proposed a barcode system called Incentive Reward Program that focuses on reducing waste in the construction site through the interrelationship between the sector chief and the warehouse handler, 
with payment of bonuses to workers who generate the least amount of construction waste;

- Evangelista, Costa, and Zanta (2010) presented a study in the city of Salvador, Bahia, Brazil, where Class A waste was recycled with the use of a recycling machine installed in situ. With this, it was possible to obtain recycled aggregates (which were used in the construction site itself), which meant savings of $45 \%$ over the cost of acquisition of the natural aggregated volume;

- Llatas (2011) presents a model that allows estimating the amount of construction waste generated during the design phase of the project to promote its prevention and recovery. Modeling factors were obtained from a Spanish case study of more than 20 dwellings. The source and types of packaging waste, residue, soil, and hazardous waste were estimated in detail and compared with other studies. The results show that the model can be implemented during the design phase, and the possibilities of reduction and recovery of construction waste can be increased much above the challenge of the European Union, which is to recover $70 \%$ by weight of the construction and demolition waste in 2020.

- Gangolells et al. (2009) propose a quantitative methodology for the forecast of environmental impact related to the construction process of residential buildings. The study presented a consistent base for comparison and creation of an environmental forecast indicator, allowing a comparison between constructors and construction sites that can be used as enterprise strategy.

- Sarkis, Meade, and Presley (2012) presented a decision-making and structure model that is based on the economic, social, and environmental aspects of sustainability for the training and selection of subcontractors and their teams in the constructed environment.
- Senaratne and Hewamanage (2015) highlight the importance of leadership in the certification process of a sustainable construction project. The research considers four leadership processes necessary to face the challenges of LEED certification: proactive planning and visualization; collective implementation; teamwork; and continuous learning and knowledge sharing.

- Athapaththu and Karunasena (2018) studied three companies in Sri Lanka and concluded that organizations have distinctive approaches to sustainable construction standards, guidelines, and policies. The enterprises adopt technologies that reduce waste, recycle materials, conserve water and energy, protect biodiversity, maintain cost effectiveness and adopt procedures that are less disturbing to the environment than standard practices. All of the companies analyzed in that study had ISO 14001 for environment management systems and are looking forward to other ISO standards for social responsibility, energy management, and occupational health and safety.

So, it turns out that there are different types of initiatives to implement the management of sustainability on construction sites that highlight the importance and timeliness of the sustainability theme. However, the companies discussed above feature partial approaches that lead to particular practices, such as the reduction and management of construction waste. In the mentioned research, proposals for an integrated model to compare of the sustainability levels at construction sites were not observed. Therefore, this article presents a guide for the sustainability measurements adopted during the implementation phase of construction work that considers different sustainability practices to encourage actions and promote their dissemination.

EXHIBIT 1 Extract of the comparison between environmental certifications and main references

\begin{tabular}{|c|c|c|c|c|}
\hline \multirow[t]{2}{*}{$\begin{array}{l}\text { LEED (U.S. Green } \\
\text { Building Council, 2009) }\end{array}$} & AQUA-HQE (FCAV, 2013) & $\begin{array}{l}\text { BREEAM } \\
\text { (BREEAM, 2009) }\end{array}$ & $\begin{array}{l}\text { Blue House Seal } \\
\text { (CEF, 2010) }\end{array}$ & \multirow[t]{2}{*}{ Checklist question } \\
\hline & \multicolumn{3}{|c|}{ 4.0. Materials and Resources } & \\
\hline \multicolumn{5}{|c|}{ Recyclable material deposit and collection } \\
\hline \multirow[t]{3}{*}{$\begin{array}{l}\text { Picking, storage, } \\
\text { deposit, and } \\
\text { collection of } \\
\text { recyclable materials }\end{array}$} & $\begin{array}{l}\text { Control of/concern for the } \\
\text { storage and selection of } \\
\text { recyclable construction } \\
\text { materials }\end{array}$ & $\begin{array}{l}\text { Picking, storage, and } \\
\text { selection of the } \\
\text { residues }\end{array}$ & $\begin{array}{l}\text { Training for the } \\
\text { management of residues } \\
\text { (rubble) }\end{array}$ & $\begin{array}{l}\text { 1. Concern with deposit and } \\
\text { collection of recyclable } \\
\text { materials }\end{array}$ \\
\hline & $\begin{array}{l}\text { Recyclable waste separation } \\
\text { center and agreement with } \\
\text { recycling cooperatives in town } \\
\text { to take the collected materials }\end{array}$ & Selective collection & $\begin{array}{l}\text { Place for selective } \\
\text { collection }\end{array}$ & $\begin{array}{l}\text { 2. Are the different types of } \\
\text { residues separated? } \\
\text { 3. Are contaminant wastes } \\
\text { separated from the others? } \\
\text { 4. Is there separation of organic } \\
\text { and inorganic garbage? } \\
\text { 5. Is there selective collection of } \\
\text { the residues in the } \\
\text { construction site? }\end{array}$ \\
\hline & $\begin{array}{l}\text { Is internal collection compatible } \\
\text { with external collection? } \\
\text { Are entrepreneurs encouraged to } \\
\text { inquire about local practices } \\
\text { for waste collection to consider } \\
\text { the appropriate systems? }\end{array}$ & & & $\begin{array}{l}\text { 6. Are the materials protected } \\
\text { from the weather? } \\
\text { 7. Are the materials stored } \\
\text { according to technical } \\
\text { specifications? }\end{array}$ \\
\hline
\end{tabular}




\section{I PROPOSAL PRESENTATION}

\subsection{Research method}

This study reports the research work developed by one of the authors within the framework of a dissertation (Zeule, 2014). The research employed the case study method proposed by Yin (2013). The initial phase consisted of a bibliographical analysis on the topic of sustainability at construction sites and in building construction and sought to identify good practices adopted in different countries. From this, a sustainability evaluation model in the form of a checklist was devised, which assertively presented the questions obtained in the comparative table. That is, the questions were formulated to guide the responses to those that were the most favorable to the adoption of sustainability. To facilitate the implementation of the checklist and the comparison of results, the list was drawn up in a spreadsheet that could be completed during the researcher's field visits using a tablet.

\subsection{The construction of the proposed model}

A comparative table of guidelines and scoring rules for the environmental certification labels was prepared to obtain a unified diagnosis for the evaluation of the sustainability implementation at construction sites. The comparative table was based on four certification programs: BREEAM (2009); LEED NC (U.S. Green Building Council, 2009); AQUAHQE (FCAV, 2013); and the Blue House Seal (CEF, 2010).

The sustainability evaluation criteria were divided into six levels according to the LEED organization, which is the most used certification levels in Brazil. The sustainability practices were classified according to:

- Sustainable construction site,

- Rational use of water,

- Rational use of energy,

- Materials and resources,

- Environmental quality, and

- Innovations and processes.

The table in Exhibit 1 shows a partial section to promote an understanding of how the comparison process of the cited references was used to develop of the checklist questions under the topic "materials and resources" in the construction site, which was further divided into subitems: "deposit and collection of recyclable materials," "construction waste management," "materials for reuse," and "certified wood." For the sake of space, only a few points are presented.

\subsection{The proposed model}

As the table in Exhibit 1 shows, to compare the certification programs, we developed a series of questions to implement the current research. So, the model was organized in six macroitems and their respective subitems as seen in the table in Exhibit 2. In the end, the sustainability evaluation model presents a checklist with 95 questions that will
EXHIBIT 2 Items from the checklist and the number of questions in each subitem

\begin{tabular}{|c|c|c|}
\hline Item 1.0 & Sustainable Construction Site & $\begin{array}{l}\text { Number of } \\
\text { questions }\end{array}$ \\
\hline 1.1 & Transport & 10 \\
\hline 1.2 & $\begin{array}{l}\text { Reduction in heat islands and thermal } \\
\text { comfort }\end{array}$ & 07 \\
\hline 1.3 & Pollution & 04 \\
\hline 1.4 & $\begin{array}{l}\text { Space development: (1) Habitat } \\
\text { protection and restoration; ( } 2 \text { ) } \\
\text { maximization of open spaces }\end{array}$ & 03 \\
\hline 1.5 & Land selection & 08 \\
\hline Item 2.0 & Rational use of water & $\begin{array}{l}\text { Number of } \\
\text { questions }\end{array}$ \\
\hline 2.1 & Rain and gray water collection & 04 \\
\hline 2.2 & Wastewater technologies & 02 \\
\hline 2.3 & Reduction of consumption & 03 \\
\hline Item 3.0 & Rational use of energy & $\begin{array}{l}\text { Number of } \\
\text { questions }\end{array}$ \\
\hline 3.1 & Local generation of renewable energy & 01 \\
\hline 3.2 & $\begin{array}{l}\text { Technologies for reduction of energy } \\
\text { consumption }\end{array}$ & 06 \\
\hline Item 4.0 & Materials And Resources & $\begin{array}{l}\text { Number of } \\
\text { questions }\end{array}$ \\
\hline 4.1 & $\begin{array}{l}\text { Recyclable materials deposit and } \\
\text { collection }\end{array}$ & 07 \\
\hline 4.2 & Management of construction residues & 08 \\
\hline 4.3 & Reuse of materials & 02 \\
\hline 4.4 & Certified wood & 02 \\
\hline Item 5.0 & Environmental quality & $\begin{array}{l}\text { Number of } \\
\text { questions }\end{array}$ \\
\hline 5.1 & $\begin{array}{l}\text { Comfort of the users of the construction } \\
\text { site and surroundings }\end{array}$ & 13 \\
\hline 5.2 & $\begin{array}{l}\text { Reduction in CFC use } \\
\text { (chlorofluorocarbon) and } \mathrm{CO}_{2} \text { (carbon } \\
\text { dioxide) }\end{array}$ & 03 \\
\hline Item 6.0 & Innovations and processes & $\begin{array}{l}\text { Number of } \\
\text { questions }\end{array}$ \\
\hline 6.1 & Innovations and processes & 12 \\
\hline Total & & 95 \\
\hline
\end{tabular}

From: Zeule (2014).

define the level of sustainability practices adopted at a given construction site.

A significant feature of this method is to point out the possible answers for each evaluation item-each question presents five alternative responses. For that, a good theoretical base as well as the identification of existent sustainability good practice at construction sites informed decision making regarding the scoring of answers (Zeule \& Serra, 2017).

The possible answers to each question were distributed to conform to a Likert scale, which considers a response range with an odd number of options. In this case, five degrees of variation was used, from 0 to 4 . The highest degree of response in the evaluation, 4 , corresponds to positive sustainability, the lowest degree, 0 , corresponds to a lack 
EX HIB IT 3 Example of checklist completed for the item "Material and Resources"

\begin{tabular}{|c|c|c|c|c|c|c|c|}
\hline 4.0. Materials and resources & 0 & 1 & 2 & 3 & 4 & NA & Scoring \\
\hline 4.1 Deposit and collection of recyclable materials & & & & & & & From 0 to 4 \\
\hline $\begin{array}{l}\text { 4.1.1 Are there concerns about the deposit and } \\
\text { collection of recyclable materials? }\end{array}$ & & & & 3 & & & 3 \\
\hline \multicolumn{8}{|l|}{$0=\mathrm{No}$} \\
\hline \multicolumn{8}{|l|}{$1=$ Very little, only one material } \\
\hline \multicolumn{8}{|l|}{$2=$ Little, two materials } \\
\hline \multicolumn{8}{|l|}{$4=$ Yes, all the materials } \\
\hline \multicolumn{8}{|l|}{ NA = cannot assign this criterion } \\
\hline 4.1.2 Are there separation areas by type of waste? & & & 2 & & & & 2 \\
\hline \multicolumn{8}{|l|}{$0=$ No } \\
\hline \multicolumn{8}{|l|}{$4=$ Yes } \\
\hline \multicolumn{8}{|l|}{ NA $=$ Cannot assign this criterion } \\
\hline $\begin{array}{l}\text { 4.1.3 Are waste contaminants separated from the } \\
\text { others? }\end{array}$ & & & & & 4 & & 4 \\
\hline \multicolumn{8}{|l|}{$0=\mathrm{No}$} \\
\hline \multicolumn{8}{|l|}{$1=$ cannot assign this criterion } \\
\hline \multicolumn{8}{|l|}{$2=$ cannot assign this criterion } \\
\hline \multicolumn{8}{|l|}{$3=$ cannot assign this criterion } \\
\hline $4=$ Yes & & & & & & $\mathrm{X}$ & \\
\hline
\end{tabular}

From: Zeule (2014).

of good practice. The possibility to mark "not applicable" (NA) was also available for studies at construction sites that do not present definitive conditions, excluding this item from the scoring. Likert scales may be presented as expressions of agreement, frequency, importance, quality, or probability. The checklist was elaborated based on the following five alternative expressions of quality:

$0=$ Does not comply with practice

$1=$ Compliance lagged

$2=$ A few factors comply

$3=$ Compliance, but lacking important factors that were not inserted

$4=$ Total compliance

$\mathrm{NA}=$ Not applicable

The table in Exhibit 3 shows an example of the checklist questions and possible answers considering the responses shown above. Each degree of response indicates the appropriate response to the situation observed at the construction site and presents the related score for that subitem for one respondent.

By completing the checklist, one can evaluate each parameter on the list. For example, the subitem, "4.1 Deposit and Collection for Recyclable Materials," in Exhibit 3 has seven questions with a maximum score of 28 points (corresponding to the maximum score 4 multiplied by seven questions in accordance with Exhibit 1). The scores of the three questions shown can be observed in Exhibit 3 and are, respectively, 3, 2, and 4. For brevity's sake, let us assume that, after answering the remaining four questions, we obtain a sum of all seven scores in the subitem of 22. Thus, the percentage score is obtained by multiplying the subitem score (22) by $100 \%$ and then dividing this number by the maximum achievable score (28) to reach the rate of compliance of $79 \%$.

As a result, subitem 4.1 shows a compliance rate or percentage of $79 \%$ for the observed practices, offering opportunities for improvement according to the guidelines that are presented. This calculation is performed for all the items on the checklist, determining the percentages of sustainable practices met in each item and subitem. According to Zeule (2014), this classification proposal was based on the certification labels assessment as cited, which, in general, established minimum compliance according to the evaluation criteria to achieve a certain level of certification. For example, LEED presents four levels of certification: Certificated (the simplest); Silver; Gold; and Platinum (the most demanding).

At the end of checklist completion, the indicator for the final classification of the site is obtained. Five levels of classification are proposed, 
EXHIBIT 4 Proposal for classification of the sustainability level of the construction site

Level $0=$ Nonsustainable site $=0 \%-20 \%$

Level 1 = site with FEW sustainable practices $=21 \%-50 \%$

Level $2=$ site with good level of sustainable practices $=51 \%-70 \%$

Level $3=$ site with optimum level of sustainable practices $=71 \%-80 \%$

Level $4=$ site with excellent level of sustainable practices $=81$-to $100 \%$

From: Zeule (2014).

organized according to the quantity and quality of practical and sustainable actions implemented, as shown in the table in Exhibit 4.

\subsection{Validation of the proposed model}

After the drafting of the proposed model, it was validated by applying it to six construction sites located in the Brazilian states of São Paulo (SP) and Ceará (CE), some of which were environmentally certified. The aim was to analyze the feasibility and applicability of the comparison method proposed by Zeule (2014). The construction sites that were visited are identified in the table in Exhibit 5.

We sought to select works that were in similar stages of execution, choosing the structural and sealing phases and seeking standardization of the activities occurring at the construction sites that were visited. The companies were selected through nominations by professionals, which facilitated contact and access to data for analysis. We also searched for construction sites with certification programs to identify whether there would be a difference in sustainability levels after the application of the checklist proposed by the model. All companies held ISO 9001 certifications (quality management system) and one had ISO 14001 (environmental management system) certification. Some projects were publicly funded and were characterized as HIS.

During the field visits, we also recorded the conditions using a camera, site document analyses, and interviews with construction and administrative team members (i.e., civil and environmental engineers or security technicians).
After the visits and completion of the six checklists, we performed data analysis and classification of the construction sites. The table in Exhibit 6 presents the results of the model application at the construction sites by items and subitems. The table in Exhibit 7 presents the general classification of the sustainability practices adoption levels.

Analyzing the table in Exhibit 7, one can observe that the work sites of structural masonry construction (Site A and Site B) had different classifications. Site $A$ had the lowest score among the six construction sites, possibly because it is just beginning the process of implementing sustainable practices. During the visit, it was noted that there was difficulty in managing the inventory and controlling materials, mainly of concrete blocks, unloaded in large quantities and without a suitable place for storage. In addition, there was no strategy for reusing or recycling the construction waste.

Site B had its best score for the item "rational use of energy" because it was the only site using renewable energy, in this case, solar energy. The item with the lowest score at the site was "rational use of water." However, if the company wanted to improve its score in regard to sustainable practices, efforts to address the "rational use of water," as suggested by the checklist, could be implemented.

The precast concrete construction works (Site C and Site D) were able to score on "innovations and processes" due to the characteristics of their innovative construction systems. Lower amounts of residue generation were observed at these sites, due to the rationalization of the constructive system.

The sites using reinforced concrete cast in situ (Sites E and F) had high finishing standards. This system is scored better than the others in the items "quality" and "adequacy," but it failed to score well for some other practices, such as the existence of workers' training, although this is probably due to this type of construction being better known to workers than the other systems studied).

The evaluation of the six sites demonstrated that good sustainability practices were highlighted by the proposed checklist. This means that the checklist can be used by construction companies as a tool for the management and implementation of practices that can improve performance at the site in relation to some aspects of sustainability.

EXHIBIT 5 Basic characteristic of the construction sites in Brazil

\begin{tabular}{|c|c|c|c|c|}
\hline Nomenclature & Constructive system & City and state & Certifications & $\begin{array}{l}\text { Type of } \\
\text { enterprise }\end{array}$ \\
\hline Site A & Structural masonry & Fortaleza, CE & ISO 9001 & Public \\
\hline Site B & Structural masonry & Pindamonhangaba, SP & $\begin{array}{l}\text { ISO } 9001 \\
\text { ISO } 14001 \\
\text { AQUA-HQE }\end{array}$ & Private \\
\hline Site C & Precast concrete & Fortaleza, CE & ISO 9001 & Public \\
\hline Site D & Precast concrete & $\begin{array}{l}\text { São Gonçalo do } \\
\text { Amarante, CE }\end{array}$ & ISO 9001 & Public \\
\hline Site $\mathrm{E}$ & Reinforced concrete & Limeira, SP & $\begin{array}{l}\text { ISO } 9001 \\
\text { AQUA-HQE }\end{array}$ & Private \\
\hline Site F & Reinforced concrete & Fortaleza, CE & $\begin{array}{l}\text { ISO } 9001 \\
\text { LEED }\end{array}$ & Private \\
\hline
\end{tabular}

From: Zeule (2014). 
EXHIBIT 6 Overall sustainability score at construction sites

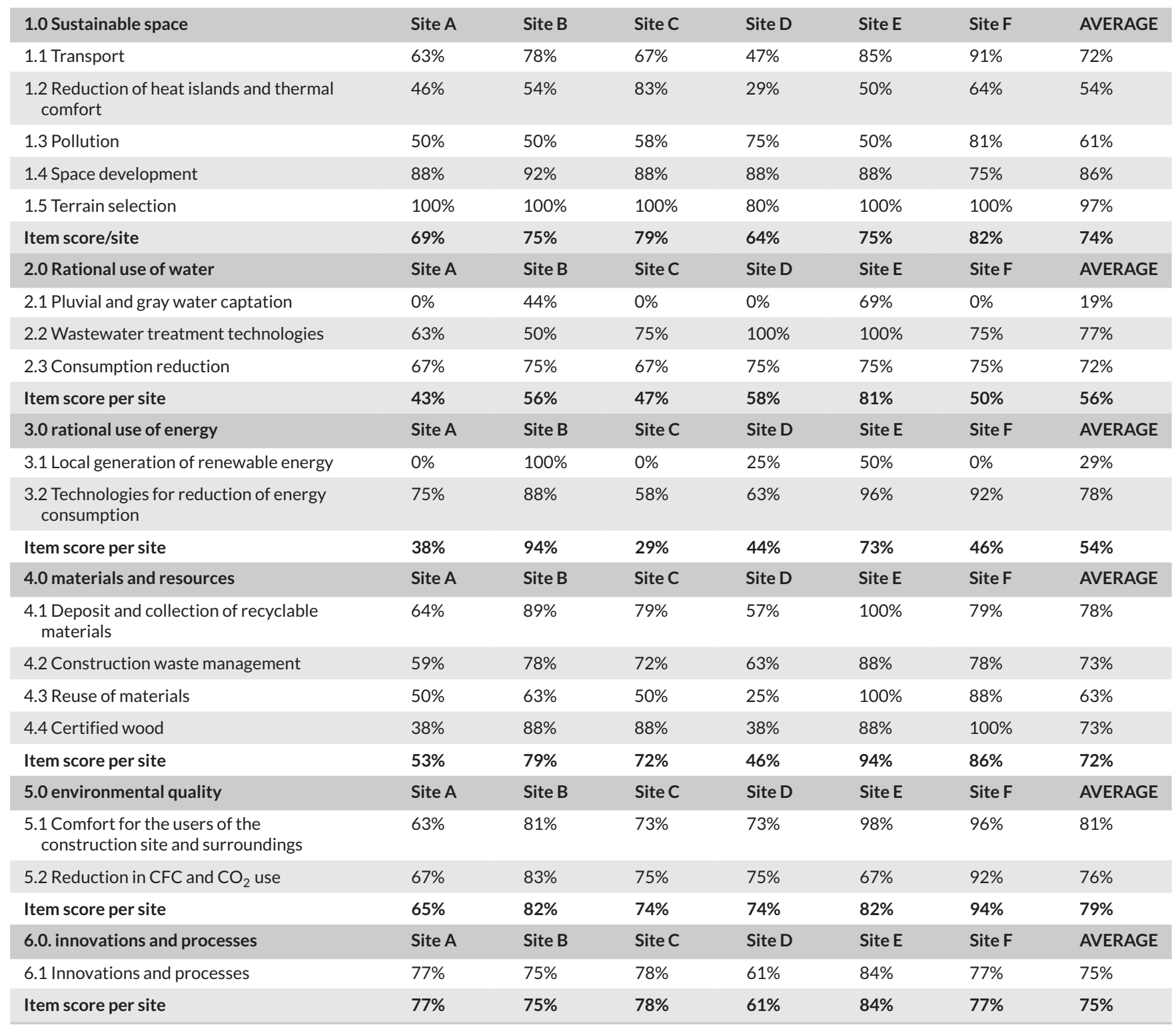

From: Zeule (2014).

EXHIBIT 7 Classification of the construction sites' sustainability

\begin{tabular}{|llll|} 
& & \multicolumn{2}{l}{$\begin{array}{l}\text { Classification of the construction } \\
\text { sites' sustainability }\end{array}$} \\
\cline { 3 - 4 } Sites & $\begin{array}{l}\text { General } \\
\text { scoring (\%) }\end{array}$ & Level & $\begin{array}{l}\text { Adopted criterion } \\
\text { classification }\end{array}$ \\
\hline Site A & 53 & Level 2 & Good \\
\hline Site B & 74 & Level 3 & Optimum \\
\hline Site C & 58 & Level 2 & Good \\
\hline Site D & 57 & Level 2 & Good \\
\hline Site E & 83 & Level 4 & Excellent \\
\hline Site F & 67 & Level 2 & Good \\
\hline
\end{tabular}

From: Zeule (2014).

\section{CONCLUSION}

Through this study, we found that it is possible to consider some of the sustainability practices at the start of a project's conception so that when the execution phase-work at the construction sitecommences, there are no incompatibilities or problems with extra costs. From the proposed model, it was possible to reach a synthesis proposal that can serve as a practical yet simplified guide for construction agents to implement sustainable practices at their construction sites.

Regarding the validation of the proposed model at construction sites, we found that there were no restrictions as to the type of construction system, nor does the model interfere with the grading of the sustainable certification processes either. Although we observed that the use of the checklist can improve the score, the scoring 
process considers only the existence and implementation of good practices.

The development of management tools, such as the proposed model for construction sites, assists in the implementation, control, and evaluation of sustainability. In this case, it also functions as a reference structure that establishes a comparison between companies and/or construction sites.

In the authors' opinion, the main contribution of this study is the early proposition of a model that considers the criteria and recommendations for sustainability implementation on construction sites independent of the region and the constructive system adopted. There is no need for the company to have environmental certification, but rather, of that strategies of sustainability become a culture within the companies, and that sustainability is present in all stages of construction, particularly during the execution phase.

\section{ACKNOWLEDGMENTS}

To the construction companies who have collaborated in the research, to CAPES (Coordination for the Improvement of Higher Education Personnel) and CANTECHIS Collaborative Net Project - Technologies for Social Housing Scheme (HIS) Sustainable Construction Sites, supported by FINEP (Financier of Studies and Projects).

\section{REFERENCES}

Ahmad, T., Thaheem, M. J., \& Anwar, A. (2016). Developing a greenbuilding design approach by selective use of systems and techniques. Architectural Engineering and Design Management, 12(1), 29-50. https://doi.org/10.1080/17452007.2015.1095709

Alarcón, L. F., \& Mardones, D. A. (1998). Improving the design construction interface. In: Proceedings of VI Congress International Group for Lean Construction (IGLC-6), Guarujá, Brazil, 1998. 12p. Retrieved from http://iglc.net/Papers/Details/34

Andrade, J., \& Bragança, L. (2016). Sustainability assessment of dwellings-A comparison of methodologies. Civil Engineering and Environmental Systems, 33(2), 125-114. https://doi.org/10.1080/ 10286608.2016.1145676

Athapaththu, K. I., \& Karunasena, G. (2018). Framework for sustainable construction practices in Sri Lanka. Built Environment Project and Asset Management, 8(1), 51-63. https://doi.org/10.1108/BEPAM-11-2016-0060

Building Research Establishment (BRE) (2009). BREEAM Europe Commercial 2009 Assessor Manual. BRE Global Ltd 2009, 346 p. Retrieved from https://tools.breeam.com/filelibrary/Technical\%20Manuals/BREEAM_ Europe_Commercial_2009.pdf

Chen, Z., Li, H., \& Wong, C. T. C. (2002). An application of bar-code system for reducing construction waste. Automation in Construction, 11(5), 521533. https://doi.org/10.1016/S0926-5805(01)00063-2

Choudhry, R. M., Gabriel, H., Khan, M. K., \& Azhar, S. (2017). Causes of discrepancies between design and construction in Pakistan construction industry. Journal of Construction in Developing Countries, 22(2), 1-18. https://doi.org/10.21315/jcdc2017.22.2.1

Construction Industry Research and Information Association. (2001). Sustainable construction: Company indicators. CIRIA Report C563. London. Retrieved from https://www.ciria.org/ItemDetail?iProductCode= C563\&Category $=$ BOOK\&WebsiteKey $=3 f 18 c 87 a-d 62 b-4 e c a-8 e f 4-$ 9b09309c1c91

Ding, G. K. (2008). Sustainable construction-The role of environmental assessment tools. Journal of Environmental Management, 86(3), 451-464. https://doi.org/10.1016/j.jenvman.2006.12.025
Dong, Y. H., \& Ng, S. T. (2016). A modeling framework to evaluate sustainability of building construction based on LCSA. The International Journal of Life Cycle Assessment, 21(4), 555-568. https://doi.org/10.1007/ s11367-016-1044-6.

Evangelista, P. P. A., Costa, D. B., \& Zanta, V. M. (2010). Sustainable alternative for the disposal of Class A construction waste: Systematic for recycling in construction sites [Alternativa sustentável para destinação de resíduos de construção classe A: Sistemática para reciclagem em canteiros de obras]. Built Environment [Ambiente Construído], 10(3), 23-40. https://doi.org/10.1590/S1678-862120100003 00002

Federal Savings Bank [Caixa Econômica Federal] (CEF). (2010). Blue house seal-Good practices for more sustainable housing [Selo Casa Azul boas práticas para habitação mais sustentável]. Vanderley M. John \& Racine T.A. Prado. São Paulo, Brazil: Pages \& Lyrics Publisher and Graphics [Páginas \& Letras Editora e Gráfica].

Foundation Carlos Alberto Vanzolini [Fundação Carlos Alberto Vanzolini] (FCAV). (2013). Certification technical reference: Residential buildings - AQUA process [Referencial técnico de certificação: Edifícios habitacionais-processo AQUA]. Alto da Lapa; Author. Retrieved from https://www.vanzolini.org.br/download/RT_Edificios_habitacionais_v2_ 2013.pdf

Gangolells, M., Casals, M., Gasso, S., Forcada, N., Roca, X., \& Fuertes, A. (2009). A methodology for predicting the severity of environmental impacts related to the construction process of residential buildings. Building and Environment, 44(3), 558-571. https://doi.org/10.1016/ j.buildenv.2008.05.001

Green Building Council (GBC) Brazil. (2018). Brazil ranks 4th in the world ranking of sustainable buildings certified by the international LEED tool (Brasil ocupa o $4^{\circ}$ lugar no ranking mundial de construçães sustentáveis certificadas pela ferramenta internacional LEED). Retrieved from https://www.gbcbrasil.org.br/brasil-ocupa-o-4o-lugar-no-rankingmundial-de-construcoes-sustentaveis-certificadas-pela-ferramentainternacional-leed/

Grunberg, P. R. M., Medeiros, M. H. F., \& Tavares, S. F. (2014). Environmental certification of housing: Comparison between LEED for Homes, AQUA Process and Blue House Seal [Certificação [ambiental de habitações: Comparação entre LEED for Homes, Processo AQUA e Selo Casa Azul]. Environment \& Society [Ambiente \& Sociedade], 17(2), 195-214. https://doi.org/10.1590/S1414-753X2014000200013

Halliday, S. (2008). Sustainable construction. Burlington, MA: ButterworthHeinemann.

Lee, W. L. (2013). A comprehensive review of metrics of building environmental assessment schemes. Energy and Buildings, 62, 403-413. https:// doi.org/10.1016/j.enbuild.2013.03.014

Llatas, C. (2011). A model for quantifying construction waste in projects according to the European waste list. Waste Management, 31(6), 12611276. https://doi.org/10.1016/j.wasman.2011.01.023

Marcelino-Sádaba, S., González-Jaen, L. F., \& Pérez-Ezcurdia, A. (2015). Using project management as a way to sustainability. From a comprehensive review to a framework definition. Journal of Cleaner Production, 99,1-16. https://doi.org/10.1016/j.jclepro.2015.03.020

Olanipekun, A. O., Chan, A. P. C., Xia, P., \& Ameyaw, E. E. (2017). Indicators of owner commitment for successful delivery of green building projects. Ecological Indicators, 72, 268-277. https://doi.org/ 10.1016/j.ecolind.2016.08.017

Sarkis, J., Meade, L., \& Presley, A. (2012). Incorporating sustainability into contractor evaluation and team formation in the built environment. Journal of Cleaner Production, 31, 40-53. https://doi.org/10.1016/ j.jclepro.2012.02.029

Senaratne, S., \& Hewamanage, P. R. (2015). The role of team leadership in achieving LEED certification in a green building project. Built Environment Project and Asset Management, 5(2), 170-183. https://doi.org/ 10.1108/BEPAM-09-2013-0036 
Shen, L. Y., Li Hao, J., Tam, V., \& Yao, H. A. (2017). Checklist for assessing sustainability performance of construction projects. Journal of Civil Engineering and Management, 13(4), 273-281. https://doi.org/10.1080/ 13923730.2007.9636447

Soto-Acosta, P., Cismaru, D. M., Vătămănescu, E. M., \& Ciochină, R. S. (2017). Sustainable entrepreneurship in SMEs: A business performance perspective. Sustainability, 8(4), 9-24. Retrieved from https://www.mdpi.com/2071-1050/8/4/342

Thomas, N. I. R., \& Costa, D. B. (2017). Adoption of environmental practices on construction sites. Built Environment [Ambiente construído], 17(4), 924. https://doi.org/10.1590/s1678-86212017000400182

U.S. Green Building Council. (2009). Leadership in energy and environmental design - LEED for New construction \& major renovation, version 2.2, reference guide (2nd edition). Retrieved from https://www.usgbc.org/ resources/leed-new-construction-v2009-current-version

Yin, R. K. (2013). Case study research: Design and methods (5th ed.). Newbury Park, CA: Sage.

Zeule, L. O. (2014). Sustainability practices and assessment on construction sites [Práticas e avaliação da sustentabilidade nos canteiros de obras]. Master's Dissertation in structures and civil construction, Federal University of São Carlos, São Carlos, 263f. Retrieved from https://repositorio.ufscar.br/handle/ufscar/4704

Zeule, L. O., \& Serra, S. M. B. (2017). Good sustainability practices on construction sites [Boas práticas de sustentabilidade em canteiros de obras. In S. M. B. Serra, D. Bastos Costa, T. A. Saurin, \& F. F. Cardoso (Eds.), Sustainable construction site technology [Tecnologia para canteiro de obras sustentável] (pp. 53-70). São Carlos, Brazil: Editora Scienza. Retrieved from https://www.researchgate.net/publication/ 319026901_Boas_Praticas_de_Sustentabilidade_em_Canteiros_de_ Obras

Zhang, Y., Wang, J., Hu, F., \& Wang, Y. (2017). Comparison of evaluation standards for green building in China, Britain, United States. Renewable and Sustainable Energy Reviews, 68, 262-271. https://doi.org/ 10.1016/j.rser.2016.09.139

Zou, P. X. W., \& Couani, P. (2012). Managing risks in green building supply chain. Architectural Engineering \& Design Management, 8(2), 143-158. https://doi.org/10.1080/17452007.2012.659507

\section{AUTHOR BIOGRAPHIES}

Zeule graduated in technology in civil construction (2011) from the State University of Maringá and obtained Ph.D. degree in structures and civil construction (2018) from Postgraduate Program in Civil Engineering at the Federal University of São Carlos, Brazil. Main research areas are sustainability in construction, decision-making method, selection of low impact materials, application of sustainability checklist, and management and planning of the construction site.

Serra is a civil engineer from the Federal University of Juiz de Fora and doctorate in civil engineering at the University of São Paulo, Brazil. She is associate professor at the Civil Engineering Department of the Federal University of São Carlos since 1994. Main research areas include construction management, planning and scheduling, subcontractor management, construction site, lean construction, sustainable construction, Building Information Modeling, and safety and health at work.

Teixeira graduated in civil engineering from the Faculty of Engineering of the University of Porto, Portugal, and obtained the degree of doctor of civil engineering from the Faculty of Engineering, Loughborough University, UK. He has been an associate professor at the Department of Civil Engineering since 1994 and a researcher at the Center for Territory Environment and Construction in the field of sustainable construction.

How to cite this article: Zeule LdO, Serra SMB, Teixeira JMC. Model for sustainability implementation and measurement in construction sites. Environ Qual Manage. 2019;29:6775. https://doi.org/10.1002/tqem.21666 